\title{
Kajian Efektivitas Implementasi Program Demonstration Farm di Kecamatan Blanakan Kabupaten Subang
}

\author{
Effectiveness Assessment Implementation on Demonstration Farm Program in District Blanakan, \\ Subang Regency
}

\author{
Sofyan Rahman ${ }^{1 *}$, Aida Vitayala S Hubeis ${ }^{2}$, dan Wini Trilaksani ${ }^{3}$
}

${ }^{1}$ Direktorat Jenderal KP3K Kementerian Kelautan dan dan Perikanan

${ }^{2}$ Departemen Manajemen, Fakultas Ekonomi Manajemen, Institut Pertatnian Bogor

Jl. Kamper, Kampus IPB Dramaga, Bogor 16680

${ }^{3}$ Departemen Teknologi Hasil Perikanan, Fakultas Perikanan dan Ilmu Kelautan, Institut Pertaninan Bogor

Jl. Agatis, Kampus IPB Dramaga, Bogor 16680

\begin{abstract}
ABSTRAK
Usaha budi daya udang dalam beberapa tahun terakhir ini mengalami berbagai permasalahan, baik yang bersifat teknis maupun non teknis sehingga menyebabkan lahan tambak tidak berfungsi (idle). Pada tahun 2012 Kementerian Kelautan dan Perikanan merumuskan program kegiatan revitalisasi yang difokuskan pada rehabilitasi saluran tambak melalui Demonstration Farm (Demfarm). Tujuan kajian adalah untuk menganalisis efektivitas implementasi program Demfarm di Kecamatan Blanakan Kabupaten Subang. Data analisis menggunakan analisis kualitatif, kuantitatif, analisis SWOT (Strenghts, Weaknesses, Opportunities, dan Threats), dan AHP (Analytical Hierarcy Process). Hasil kajian implementasi Demfarm di Kecamatan Blanakan Kabupaten Subang cukup efektif. Wilayah Kecamatan Blanakan Kabupaten Subang merupakan area tambak udang yang ideal, penerapan teknologi Demfarm mampu meningkatkan produktifitas tambak dari 0-17 ton/ha menjadi 7-7,5 ton/ha, serta terjalinnya sistem kemitraan antara petambak dengan pihak swasta. Usaha tambak udang memiliki IFE 0,148 dan EFE 0,495, faktor terpenting pengembangan usaha tambak udang di Kecamatan Blanakan Subang adalah teknologi dengan nilai 0,341. Usaha udang layak dikembangkan, nilai Benefit Cost Ratio (B/C ratio) $>1$, Net Present Value (NPV) yang dihasilkan $>0$ Break Event Point (BEP) produksi terendah $7.000 \mathrm{~kg}$ dan tertinggi $7.500 \mathrm{~kg}$ selanjutnya BEP harga terendah Rp60.000 dan tertinggi Rp70.000.
\end{abstract}

Kata kunci: demfarm, petambak, produktivitas, udang

\begin{abstract}
In recent years, shrimp farming have experienced a variety of problems, both technical and nontechnical, causing the shrimp farm do not work properly (idle). In 2012 the Ministry of Maritime Affairs and fisheries formulate revitalization program which focused on the rehabilitation ponds channel through Demonstration Farm (Demfarm) program. The purpose of this study is to analyze the effectiveness of the implementation of the Demfarm program in the Blanakan District in Subang regency. The data has been analyze using qualitative analysis, quantitative analysis, SWOT analysis (Strengths, Weaknesses, Opportunities, and Threats), and AHP (Analytical Hierarchy Process). The result of the study shows that Demfarm implementation in Blanakan District, Subang Regency is quite effective. Blanakan District in Subang Regency is an ideal area for shrimp farm, the application of Demfarm technology can improve the productivity of farms from 0-17 up to 7-75 tons / ha, the programs also help to establish the partnership system between farmers and the private sector. Shrimp farms have 0.148 IFE and $0.495 \mathrm{EFE}$, another most important thing for shrimp farming development in the Blanakan District is technology have 0.341 . Shrimp farming worth to be developed, the value of Benefit Cost Ratio (B/C ratio) $>1$, the Net Present Value (NPV) generated $>0$ Break Event Point (BEP) the lowest production $7000 \mathrm{~kg}$
\end{abstract}

Korespondensi:

*) Gd. Mina Bahari III lt.3 Jl. Medan Merdeka Timur No.16, Jakarta Pusat 10110; e-mail: sofyan.rahman46@gmail.com 
and the highest production is $7.500 \mathrm{~kg}$, for BEP the lowest price is $\mathrm{Rp} .60000$ and the highest price is Rp.70.000.

Key words: demfarm, farmer, productivity, shrimp

\section{PENDAHULUAN}

Potensi pengembangan budi daya udang di Indonesia sangat terbuka karena kondisi biofisik perairan yang sangat mendukung budi daya tambak serta pasar yang masih sangat terbuka, baik di mancanegara maupun nasional. Namun potensi besar tersebut tidak diiringi dengan produktivitas udang nasional, Laporan Akuntabilitas Kinerja Kementerian Kelautan dan Perikanan (KKP) Tahun 2012 menyebutkan bahwa capaian produksi udang hanya $86,5 \%$ (458.000 ton) dari target produksi. Salah satu penyebab adalah banyaknya tambak idle sehingga memengaruhi produksi. Udang sebagai salah satu komoditas ung-gulan nasional yang telah dirumuskan dalam Rencana Program Jangka Menengah Nasional (RPJMN) 2010-2014 bahwa sektor perikanan sebagai salah satu prioritas pembangunan nasional.

Kecamatan Blanakan memiliki luas areal tambak mencapai 340 ha (Subang Angka, 2010) sehingga Kecamatan Blanakan dikenal dengan wilayah tambak udang. Produktivitas udang di Kecamatan Blanakan Subang sangat rendah hal ini disebabkan adanya serangan virus pada komoditas udang windu yang rentan terhadap penyakit selain penggunaan teknologi masih sederhana juga usaha tambak udang dilakukan secara individu. Akibat kondisi tersebut para petambak banyak beralih profesi ke usaha bidang lain sehingga terjadi lahan iddle (lahan tidur).

Salah satu alternatif budi daya udang yang dilakukan beberapa petambak adalah dengan menggunakan teknologi plastik mulsa, pengelolaan tambak pola intensif dengan penggunaan teknologi plastik mulsa diyakini dapat meningkatkan produksi dan keuntungan (Maulina, 2012). Karenanya teknologi plastik mulsa menjadi pilihan yang tepat pada program Demfarm tambak udang.

Demfarm dapat mengoptimalkan lahan ideal, meminimalisir kegagalan dan meningkatkan produktivitas serta ramah lingkungan untuk menjaga keberlangsungan usaha. Kegiatan percontohan Demfarm bersifat stimulan dengan harapan dapat dijadikan sebagai peluang usaha yang menguntungkan dan memberikan lapangan usaha serta menyerap banyak tenaga kerja dalam rangka mewujudkan empat pilar pembangunan nasional, yaitu keberpihakan pada masyarakat miskin (pro-poor) peningkatan lapangan pekerjaan (pro-job), meningkatkan pertumbuhan ekonomi (pro-growth), kepedulian terhadap kelestarian dan keberlanjutan pada lingkungan (proenvironment).

Program Demfarm merupakan stimulan untuk merangsang minat petambak udang untuk membuka kembali lahan-lahan tambak yang selama ini dianggap sudah tidak berfungsi (idle). Demfarm udang di Kecamatan Blanakan Subang menerapkan teknologi penggunaan plastik mulsa yang menekan serangan bakteri karena mendorong terbentuknya bioflok, yaitu pakan alami yang dihasilkan dari limbah ammonia dan nitrit sisa dari pakan yang memiliki kandungan nutrisi baik (Anggoro, 2013), manfaat lainnya dapat menstabilkan kualitas air, dan menjadi substitusi pakan yang memiliki kontribusi tertinggi pada budi daya udang, Biofloc systems were developed to improve environmental control over production. In places where water is scarce or land is expensive, more intensive forms of aquaculture must be practiced for cost-effective production. There are strong economic incentives for an aquaculture business to be more efficient with production inputs, especially the most costly (feed) and most limiting water or land (Hargreaves, 2013).

Posisi tawar petambak sangat rendah karena para petambak tidak memiliki kemampuan untuk meningkatkan nilai jual hasil panen sehingga harga rata-rata panen udang sangat tergantung oleh tengkulak selain itu juga minimnya sarana dan prasarana tambak yang dimiliki. Berkelompok adalah membentuk suatu kelembagaan yang tujuannya agar memiliki daya saing dan nilai tawar yang tinggi dan dapat menentukan harga panennya sendiri tanpa ketergantungan oleh tengkulak serta adanya sarana dan prasarana tambak yang memadai. Hal ini sependapat dengan Chusnul (2010), yang menyatakan bahwa campur tangan pemerintah mutlak diperlukan utamanya untuk memberikan kepastian harga udang kepada Petambak dan pembinaan usaha budi daya secara intensif dengan cara demplot. Pemerintah pusat KKP dan pemerintah Kabupaten Subang memfasilitasi pemberdayaan kelembagaan pelaku utama perikanan yang dikenal dengan Kelompok Pembudidaya Ikan (Pokdakan) 
sesuai dengan Kepmen. KP. No. 14/2012. Asosiasi ataupun bentuk kelembagaan lain yang berkaitan dengan Petambak memiliki peran penting untuk memberikan informasi teknologi, sebagaimana yang pernyataan berikut "Considering the intricacy of the shrimp farming activity, it is recommended that more focus should be given to information sharing and technology dissemination. It is suggested that it should be a joint effort by various institution. Existing associations can function as the closest point to the farmers. Formal institution can give the contribution by updating the information on a regular basis" (Florina, 2012).

Kelompok pembudidaya ikan menjadi prasyarat terlaksananya program demfarm yang mempermudah fasilitasi sarana dan prasarana dan akses permodalan tambak. Kelembagaan pada dasarnya merupakan suatu wadah yang merupakan wahana untuk mengkaji berbagai aspek yang berkaitan dengan tujuan untuk selanjutnya menetapkan, mengelola dan mengendalikan berbagai keputusan-keputusan untuk mencapai tujuan yang diinginkan (Sholahuddin, 2001).

Penelitian bertujuan untuk (1) menganalisis implementasi program Demfarm di Kecamatan Blanakan Kabupaten Subang; (2) menganalisis faktor-faktor internal dan eksternal yang mempengaruhi keberhasilan usaha budi daya tambak udang di Kecamatan Blanakan Kabuaten Subang; dan (3) menganalisis kelayakan usaha budi daya tambak udang anggota kelompok peserta program Demfarm di Kecamatan Blanakan Kabupaten Subang.

\section{METODE PENELITIAN}

Indikator keberhasilan implementasi program Demfarm ditinjau dari tiga aspek yaitu: (1) Program (kebijakan) (2) Target Kelompok, yaitu pembudidaya udang yang menerima manfaat dari program ini dengan harapan dapat terjadi perubahan atau peningkatan dan (3) unsur pelaksana Demfarm, pemerintah pusat (KKP) yang mengkordinir, mengawal dan mengawasi proses implementasinya. Keterpaduan dalam pembangunan perikanan memerlukan koordinasi mulai dari tahapan perencanaan, pelaksanaan, pemantauan dan pengendaliannya. Untuk itu dibutuhkan visi, misi, strategi, kebijakan dan perencanaan program yang dinamis (Umar Abidin 2011).

Lokasi penelitian dilaksanakan di Kecamatan Blanakan Kabupaten Subang. Data yang digunakan meliputi data primer yaitu data yang diperoleh dari para petambak udang, keadaan sebelum dan sesudah melaksanakan Demfarm, sedangkan data sekunder yaitu data yang diambil dari laporan dan penelitian terdahulu, data dinas setempat dan KKP. Target penelitian adalah seluruh anggota kelompok demfarm yaitu 30 orang terbagi dalam 3 kelompok (Mina mandiri, Mina Samudera dan Putra Mekar).

Pengolahan dan analisis yang dilakukan: (1) Kualitatif untuk mengetahui efektivitas implementasi program dengan tujuan Demfarm; (2) kuantitatif untuk mengukur produktifitas tambak demfarm, analisa usaha dan kelayakan usaha; (3) analisa SWOT (Strengths, Opportunity, Weakness Threats) menganilis faktor kekuatan, kelemahan, peluang serta ancaman; dan (4) analisis AHP (Analytical Hierarcy Process) menganalisis permasalahan dan memasukan pertimbangan untuk menghasilkan skala prioritas dalam menentukan kebijakan.

\section{HASIL DAN PEMBAHASAN}

\section{Potensi Tambak Udang di Kecamatan Blanakan Kabupaten Subang}

Potensi tambak terbesar di Kabupaten Subang terdapat di Kecamatan Blanakan. Di Kecamatan Blanakan, terdapat 2.527 rumah tangga/ perusahaan perikanan dengan produksi 13.610 ton. Luas tambak Kecamatan Blanakan 568,25 Ha dengan status milik sendiri dan 2.849, 68 Ha milik Perhutani.

Berdasarkan potensi tersebut maka pada Tahun 2012 Pemerintah Pusat melalui Kementerian Kelautan dan Perikanan menetapkan kegiatan revitalisasi tambak di Kabupaten Subang lebih difokuskan pada komoditas udang. Perkembangan hasil produksi udang di Kabupaten Subang cukup prospektif. Dari luas areal 360 Ha Demfarm tambak udang diproduksi sebanyak 846.760 ton dengan tambahan areal budidaya seluas $50 \mathrm{Ha}$.

\section{Implementasi Usaha Tambak Udang di Keca- matan Blanakan}

Usaha tambak udang di Kecamatan Blanakan Kabupaten Subang merupakan aktivitas turun temurun (tradisi) sehingga sebagian besar masyarakat Kecamatan Blanakan berprofesi sebagai petambak udang. Sejak Tahun 2012 Kementerian Kelautan dan Perikanan telah merintis program revitalisasi tambak termasuk di Keca- 
matan Blanakan merupakan salah satu wilayah yang menjadi program prioritas yang dinamakan produksi tambak udang dengan metode Demfarm.

Sasaran dari kegiatan Demfarm tersebut adalah kelompok-kelompok petambak yang bertujuan untuk mempermudah dalam penerapan dan alih teknologi sehingga dapat menyebar dengan cepat dikalangan petambak itu sendiri. Teknologi budidaya udang pada kawasan dalam rangka revitaliasasi tambak menerapkan model managemen kluster atau kawasan. Indikator dalam implemetasi meliputi: (1) keadaan wilayah dan perkembangan wilayah; (2) kelompok sasaran; (3) teknis pelaksanaan program; (4) penggunaan dana program; (5) kesesuaian program dengan kelompok sasaran; dan (6) partisipasi sasaran dalam program (Rahaju T, 2007).

Dalam menyusun strategi kebijakan pembangunan untuk masa depan diperlukan adanya suatu pergeseran paradigma dari strategi import substitution industry menjadi resource based industry (Mudiastuti, et al, 2014), pernyataan tersebut menegaskan bahwa mencuatnya model pembangunan yang berbasis komunitas ini tidak hanya didasarkan pada pengalaman kegagalan strategi dan kebijakan pembangunan nasional pada masa lalu, tetapi juga pengalaman negaranegara maju yang kemudian mendorong terjadinya reorientasi dan perubahan paradigma pembangunan dari ekonomi sebagai sentral kepada manusia sebagai pusat utama pembangunan (Munandar, 2008). Oleh karenanya kegiatan Demfarm merupakan rangkaian proses produksi udang secara terpadu dengan menerapkan teknologi mulsa yang melibatkan unsur pemerintah, swasta, mitra dan perbankan. Syarat lokasi memenuhi kelayakan teknis untuk kegiatan usaha budidaya udang vaname. Pokdakan memiliki status kepemilikan lahan yang jelas, dan diprioritaskan di lokasi yang telah tersedia infrastruktur pendukung seperti akses jalan dan saluran air serta lokasi pertambakan yang calon Pokdakan bersedia untuk direhabilitasi. Lokasi demfarm ditetapkan Direktur Jenderal Perikanan Budidaya dengan surat keputusan Dirjen Perikanan Budidaya Kementerian Kelautan dan Perikanan.

Jumlah Pokdakan di Kecamatan Blanakan Kabupaten Subang sebagai penerima Demfarm terdiri dari tiga yaitu: Pokdakan Mina Mandiri, Mina Samudra dan Putra Mekar dengan masingmasing anggota sepuluh orang. Mitra usaha dalam Demfarm di Kecamatan Blanakan Kabupaten
Subang terdiri dari Koperasi Unit Desa Mina Karya Bukti Sejati berperan sebagai stabilitas atau penjamin pasar dengan harga yang telah ditentukan (mengikat) oleh koperasi selain itu sebagai fasilitator investor dan PT Central Proteinaprima adalah perusahaan pakan udang yang berperan memfasilitasi layanan teknis dan cara pemberian pakan udang yang baik dan tepat. Pokdakan yang membeli pakan di PT Central Proteinaprima akan didampingi oleh teknisi pakan hingga udang tersebut siap panen.

Kementerian Kelautan dan Perikanan melalui UPT KKP yang yang berada di Kabupaten Karawang memberikan bantuan teknisi dari sisi teknologi pengendalian hama penyakit dan kualitas air. Teknisi ini melakukan pengontrolan penyakit dan kualitas air setiap dua minggu. Selain itu Pemerintah memberikan sarana dan prasarana tambak seperti kincir, mesin pompa dan mulsa sebagai stimulan bagi Pokdakan.

a. Persiapan Lahan

Meliputi: (1) pematang utama harus Kedap/ tidak bocor; (2) pengedapan dan peninggian; (3)Pemasangan Sarana Biosekuriti; (4) Pengeringan tambak dan aplikasi disinfektan; (5) Perbaikan konstruksi tambak; dan (6) Pemasangan plastik mulsa.

b. Persiapan Air

Beberapa hal yang perlu diperhatikan antara lain: (1) Air pasok sudah melalui proses pengendapan dan filterisasi; (2) penggunaan pestisida dan disinfektan untuk pembasmi hama dan penyakit; (3) Perawatan saluran; (4) pengelolaan kualitas air tambak; dan (5) pembuangan limbah.

c. Penebaran Benur

Sebelum ditebar, harus dipastikan kembali bahwa pakan alami atau probiotik serta jentik nyamuk telah tumbuh di dalam kolom air. Penebaran benur dilakukan setelah dilakukan adaptasi yang dilakukan dengan dua cara sederhana yaitu: (1) adaptasi suhu plastik wadah benur direndam selama 15-30; dan (2) adaptasi kadar garam dan $\mathrm{pH}$ dilakukan dengan cara memercikkan air tambak ke dalam plastik selama 5-7 menit

d. Pemeliharaan Udang

Pemeliharaan meliputi: (1) pengelolaan kualitas air secara harian; (2) Pengendalian Kesehatan udang dan Lingkungan; (3) dan pengelolaan pakan udang, pemberian pakan memperhatikan bobot udang yang dilakukan sampling secara berkala dengan menggunakan anco. 
e. Panen udang

Beberapa hal yang perlu diperhatikan dalam panen udang yaitu: (1) Panen dilakukan setelah mencapai ukuran pasar (marketable size) 110-120 hari dengan target ukuran akhir 18-20 g/ekor, SR $80 \%$ dan FCR 1,5; (2)Tiga-empat hari sebelum dipanen dilakukan penyiponan dasar tambak agar bersih dan lumpur tidak menyebar ke seluruh petakan tambak; (3) Panen dilakukan pada pagi hari dan hindari pada saat bulan purnama

Masa waktu pemeliharaan udang ditambak berkisar 3-4 bulan tergantung pada kondisi iklim dan kualitas udang.

\section{Karakteristik Responden}

Usaha tambak udang banyak diminati oleh kalangan usia 36-45 tahun (23,33\%), usia 46-50 tahun (20\%), usia 61-65 tahun (13,33\%), usia $20-34$ tahun $(6,67 \%)$ usaha tambak udang di Kecamatan Blanakan Subang banyak diminati oleh usia 36-45 tahun yaitu usia produktif sehingga memungkinkan usaha tambak dapat berkembang dengan baik

Pendidikan pembudidaya udang di Kecamatan Blanakan Subang adalah ber pendidikan SD $(56,67 \%)$, SMA $(20,00 \%)$, pendidikan SMP $(16,67 \%)$, dan sarjana $(6,67 \%)$. Minimnya pendidikan merupakan indikator lemahnya sumber daya manusia pembudidaya udang.

Pengalaman usaha tambak di Kecamatan Blanakan Subang beragam, pengalaman 6-10 tahun $(46,67 \%)$, pengalaman 3-5 tahun $(30,00 \%)$, pengalaman $1-2$ tahun $(16,67 \%)$. Dan pengalaman $>10$ tahun $(6,67 \%)$ petambak telah berpengalaman lebih dari sepuluh tahun. Pengalaman usaha telah dikembangkan secara turun temurun sehingga stiuasi pertambakan udang sudah dikuasai oleh para petambak.

\section{Analisa SWOT}

\section{Identfikasi Faktor Kekuatan, Kelemahan, Peluang dan Ancaman}

Kekuatan, terdiri atas beberapa faktor kunci, seperti pekerja berpengalaman, benur berlimpah, kesesuian potensi lahan, pengelolaan tambak berkelompok, mudah mencari pembeli, dan nilai ekonomi tinggi. Sementara kelemahan, terdiri atas peralatan produksi sederhana, posisi tawar petambak lemah, kekurangan modal untuk pe-ngembangan usaha, kurangnya sarana dan prasarana, penjualan dilakukan pada tengkulak, dan sulit mendapat bibit berkualitas.
Dari peluang eksternal, meliputi kebijakan pemerintah, potensi lahan tambak besar, bantuan sarana tambak, tenaga pendamping teknis dan kelembagaan, penggunaan teknologi plastik mulsa, dan potensi pasar besar. Ancaman terdiri atas cuaca, harga tidak stabil, serangan virus, tengkulak, alih fungsi lahan tambak, dan impor udang.

\section{Identifikasi matriks IFE dan EFE}

Faktor strategik internal diuraikan untuk mengetahui kekuatan dan kelemahan yang dihadapi oleh petambak udang, sebagaimana tertuang dalam Tabel 1. Faktor strategik eksternal diuraikan untuk mengetahui peluang dan ancaman yang dihadapi oleh petambak udang, kemudian diidentifikasi faktor eksternal yang paling berpengaruh sebagaimana dalam Tabel 2.

\section{Analisis Matrik Internal dan Ekternal (IE)}

Penentuan posisi strategi pengembang usaha dalam matriks IE didasarkan pada hasil total nilai matriks IFE yang diberi bobot pada sumbu $X$ dan total nilai matriks EFE pada sumbu Y. Total nilai matriks IFE -0,148 dan nilai matriks EFE 0,459. posisi pengembangan udang yaitu strategi S-O, yaitu strategi ini didapatkan dengan memanfaatkan dan memaksimalkan kekuatan yang dimiliki oleh pembudidaya tambak udang untuk memanfaatkan peluang.

\section{Formulasi Strategi Pengembangan Usaha}

1. Strategi S-O (kombinasi $\mathrm{S}_{1}-\mathrm{S}_{6}$ dengan $\mathrm{O}_{1}-\mathrm{O}_{6}$ ). Alternatif strategi yang diperoleh sebagai berikut: (1) Optimalisasi produksi udang secara berkelanjutan; dan (2) Peningkatan teknologi budidaya udang secara intensif;

2. Strategi $\mathrm{S}-\mathrm{T}$ (kombinasi $\mathrm{S}_{1}-\mathrm{S}_{6}$ dengan $\mathrm{T}_{1}-\mathrm{T}_{6}$ ). Beberapa alternatif strategi yang diperoleh sebagai berikut: (1) Pengaturan pola produksi; (2) Pengendalian hama penyakit melalui budidaya intensif; dan (3) Penyusunan kerjasama pemasaran.

3. Strategi $\mathrm{W}-\mathrm{O}$ (kombinasi $\mathrm{W}_{1}-\mathrm{W}_{6}$ dengan $\mathrm{O}_{1}-\mathrm{O}_{6}$ ). Formulasi strategi yang diperoleh sebagai berikut: (1) Pengaturan pola produksi udang; (2) Perkuat kelambagaan petambak melalui pendampingan; (3) Akses permodalan melalui lembaga perbankan; dan (4) Memperkuat kelembagaan pasar melalui pemberdayaan kelompok.

4. Strategi $\mathrm{W}-\mathrm{T}$ (kombinasi $\mathrm{W}_{1}-\mathrm{W}_{6}$ dengan $\mathrm{T}_{1}-\mathrm{T}_{6}$ ) Diperoleh beberapa formulasi strategi sebagai berikut: (1) Fasilitasi permodalan, infrastruktur dan sarpras budidaya; (2) Penerapan CBIB 
udang secara berkesinambungan; dan (3) Penguatan pola kemitraan dengan lembaga lain.

Lebih lengkap hasil analisis SWOT dapat dilihat pada Tabel 3.

\section{Analytical Hierarcy Process (AHP)}

Hasil analisis AHP (Gambar 1) menunjukkan bahwa pengembangan produktivitas tambak di Kecamatan Blanakan sangat dipengaruhi oleh teknologi $(0,341)$, sumber daya manusia $(0,258)$, modal $(0,181)$, sumber daya alam $(0,129)$, dan infrastruktur (0.091), sehingga dalam menentukan kebijakan maupun penyusunan strategi harus berdasarkan pertimbangan penerapan teknologi yang tepat guna kedua sumberdaya alam ketiga permodalan keempat sumberdaya alam dan kelima infrastruktur. Aktor yang berperan dalam pengembangan teknologi adalah pemerintah yang dipandang cakap sehingga alternatif strategi penerapan teknologi melalui CBIB sesuai dengan daya dukung lingkungan.

Tabel 1. Matriks IFE pengembangan usaha udang Kecamatan Blanakan Kabupaten Subang

\begin{tabular}{|c|c|c|c|c|}
\hline No & Faktor Strategik Internal & Bobot (a) & Rating (b) & Bobot $x$ Rating $(a \times b)$ \\
\hline \multicolumn{5}{|c|}{ Kekuatan } \\
\hline 1 & Pekerja yang berpengalaman & 0,052 & 3,6 & 0,188 \\
\hline 2 & Benur berlimpah & 0,082 & 3,0 & 0,245 \\
\hline 3 & Kesesuaian potensi lahan & 0,107 & 3,8 & 0,407 \\
\hline 4 & Pengelolaan tambak secara berkelompok & 0,078 & 3,4 & 0,264 \\
\hline 5 & Mudah mencari pembeli & 0,099 & 4,2 & 0,415 \\
\hline 6 & Nilai ekonomi yang tinggi & 0,075 & 4,2 & 0,314 \\
\hline \multicolumn{5}{|c|}{ Kelemahan } \\
\hline 1 & Peralatan produksi sederhana & 0,041 & $-2,8$ & $-0,115$ \\
\hline 2 & Posisi tawar petambak lemah & 0,087 & $-2,8$ & $-0,245$ \\
\hline 3 & $\begin{array}{l}\text { Kekurangan modal untuk pengembangan } \\
\text { usaha }\end{array}$ & 0,092 & $-4,0$ & $-0,367$ \\
\hline 4 & Kurangnya sarana dan prasarana & 0,085 & $-4,0$ & $-0,339$ \\
\hline 5 & Penjualan dilakukan kepada tengkulak & 0,075 & $-2,8$ & $-0,209$ \\
\hline 6 & Sulit mendapatkan bibit berkualitas & 0,128 & $-3,2$ & $-0,411$ \\
\hline & Jumlah & 1,000 & & 0,148 \\
\hline
\end{tabular}

Tabel 2. Matriks EFE pengembangan usaha udang Kecamatan Blanakan Kabupaten Subang

\begin{tabular}{clccc}
\hline No & \multicolumn{1}{c}{ Faktor Strategik Eksternal } & Bobot $(\mathrm{a})$ & Rating $(\mathrm{b})$ & Bobot $\times$ Rating $(\mathrm{a} \times \mathrm{b})$ \\
\hline \multicolumn{2}{c}{ Peluang } & & & \\
1 & Kebijakan Pemerintah & 0,075 & 4,0 & 0,299 \\
2 & Potensi lahan tambak yang besar & 0,090 & 3,8 & 0,343 \\
3 & Bantuan sarana tambak & 0,075 & 4,4 & 0,328 \\
4 & Tenaga pendamping teknis dan kelembagaan & 0,087 & 4,6 & 0,402 \\
5 & Penggunaan teknologi plastik mulsa & 0,079 & 4,0 & 0,315 \\
6 & Potensi pasar besar & 0,087 & 4,6 & 0,402 \\
\hline Ancaman & & & $-0,311$ \\
1 & Cuaca & 0,092 & $-3,4$ & $-0,270$ \\
2 & Harga tidak stabil & 0,085 & $-3,2$ & $-0,402$ \\
3 & Serangan virus & 0,118 & $-3,4$ & $-0,198$ \\
4 & Tengkulak & 0,062 & $-3,2$ & $-0,248$ \\
5 & Alih fungsi lahan tambak & 0,089 & $-2,8$ & $-0,198$ \\
6 & Impor udang & 0,062 & $-3,2$ & 0,459 \\
\hline
\end{tabular}


Tabel 3. Analisa SWOT pengembangan budidaya udang sistem Demfarm, 2015

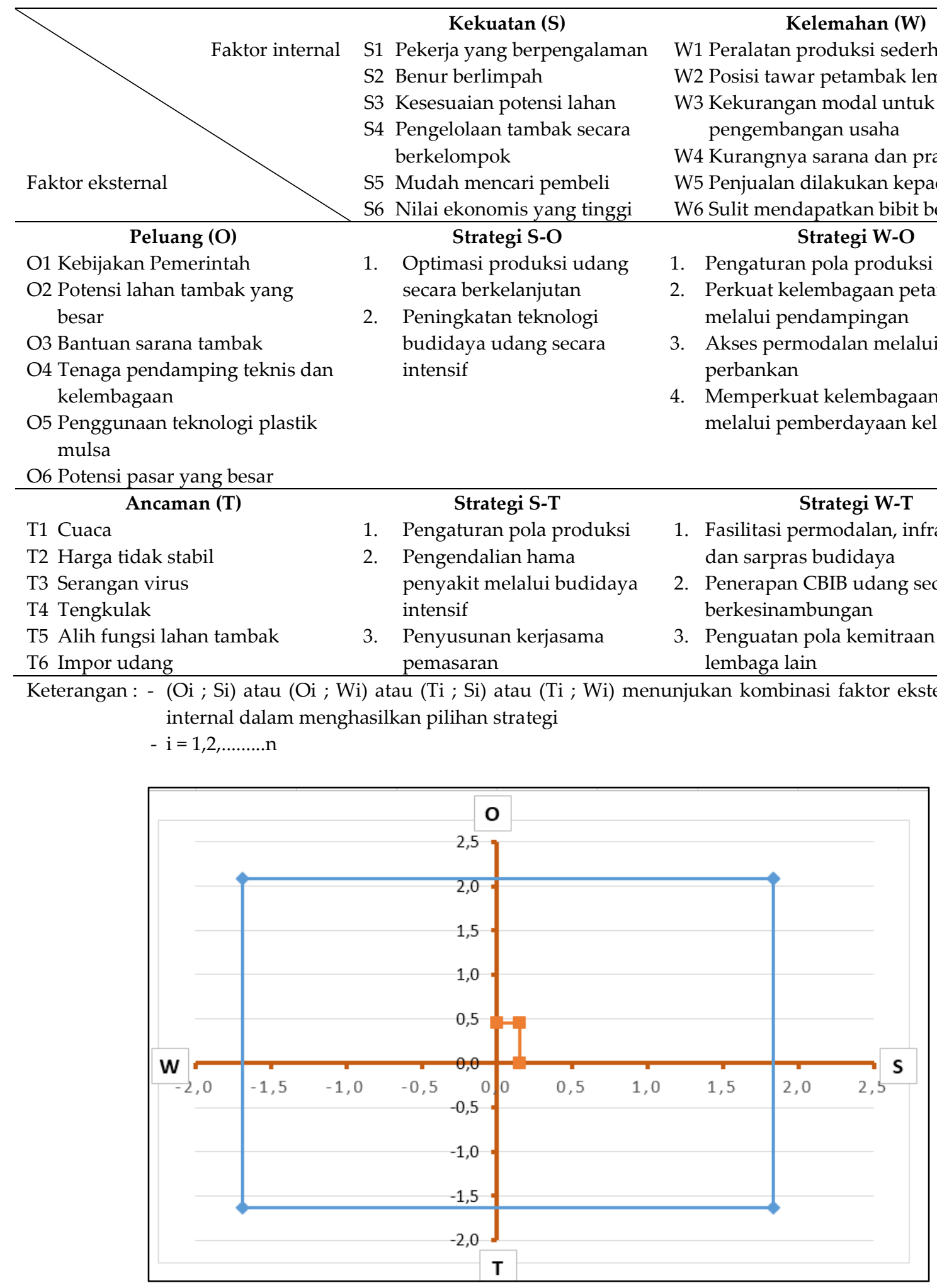

Gambar 1. Posisi strategi internal dan eksternal dalam pengembangan usaha Udang di Kecamatan Blanakan Kabupaten Subang

\section{Analisa Data Kuantitatif}

\section{Produktivitas tambak udang}

Sebelum adanya program Demfarm, produktivitas tambak rataan 0,017 ton/ha. Setelah adanya Demfarm mampu meningkatkan produk- tivitas tambak antara 7-75 ton/ha. Kondisi demikian memberikan dukungan bahwa pengembangan usaha tambak di Kecamatan Blanakan Subang dapat dilanjutkan. 


\section{Analisa Finansial}

Pengembangan usaha tambak udang dengan demfarm memberikan keuntungan Rp50 juta sampai dengan Rp100 juta (16,67\%), Rp101 juta sampai dengan Rp200 juta (30\%), keuntungan 201 juta sampai dengan Rp300 juta (26\%), dan Rp301 juta sampai dengan 400 juta (16.67\%).

Penjualan udang dilakukan bervariasi, tengkulak, mitra dan koperasi, harga tertinggi mencapai Rp70.000 sedangkan harga terendah Rp60.000. Dengan hasil panen yang dihasilkan oleh para petambak berkisar antara 7000-8000 kg per siklus. Pendapatan yang diperoleh Rp100 juta sampai dengan Rp500 juta (30\%), pendapatan Rp501 juta sampai dengan Rp1 milyar (20\%), pendapatan Rp1 milyar sampai dengan Rp1,5 milyar $(33,33 \%)$, dan pendapatn diatas Rp1,5 milyar (16,67\%).

\section{Kelayakan Usaha}

Usaha pengembangan tambak udang di Kecamatan Blanakan Subang layak untuk dikembangkan, Benefit Cost Ratio (B/C ratio) mempunyai nilai $>1$ artinya setiap cost yang dikeluarkan akan memberikan 1-2 manfaat terhadap investasi tambak udang yang dilakukan. $\mathrm{B} / \mathrm{C}$ ratio $1,00-1,30$ sebanyak $60 \%, 1,31-1,40 \mathrm{~B} / \mathrm{C}$ ratio sebanyak 33,33 persen, dan $\mathrm{B} / \mathrm{C}$ ratio $>1,40$ sebanyak 6,67 persen.

Sebanyak 50 persen usaha tambak udang di Kecamatan Blanakan Kabupaten Subang akan mengalami titik impas produksi atau BEP Produksi apabila panen yang dihasilkan 5-10 ton, sebanyak 33,33 persen BEP produksi apabila panen berkisar antara 11-20 ton, dan sebanyak 16,67 persen. mengalami BEP produksi apabila panen $>20$ ton. BEP harga akan terjadi apabila harga jual berkisar Rp. 41.000-Rp.50.000 (20\%), harga jual berkisar Rp.51.000-Rp.60.000 (80,00\%). Harga jual udang di Kecamatan Blanakan Subang rataan $\mathrm{Rp} .65 .000 / \mathrm{kg}$.

Net Present Value (NPV) diartikan sebagai salah satu indikator layak tidaknya sebuah usaha untuk dikembangkan. NPV juga disebut sebagai manivestasi sekarang yang akan dicerminkan dimasa mendatang. Masa usia tambak di Kecamatan Blanakan Subang adalah dua tahun dengan discount faktor sebesar 20 persen maka diperoleh usaha tambak yang dikembangkan adalah secara umum memiliki nilai NPV $>1$ artinya usaha tambak yang kembangkan di Kecamatan Blanakan Subang layak untuk diusahakan.
Tambak udang melalui program Demfarm di Kecamatan Blanakan Kabupaten Subang didapatkan sebanyak 23,33\% responden usaha yang dikembangkan menghasilkan IRR > 50, 43\% responden menghasilkan IRR 21-30\%, 23\% responden usaha yang dikembangkan menghasilkan IRR $31-41 \%$, dan $53,67 \%$ responden menghasilkan IRR 41-50\%. Usaha tambak udang yang dikembangkan di Kecamatan Blanakan menghasilkan IRR 20-50\%. Dapat disimpulkan bahwa usaha tersebut memberikan keputusan yang positif dan pengembangan usahanya dapat dilanjutkan.

Tingkat suku bunga pengembalian usaha tambak udang di Kecamatan Blanakan Subang dengan proyeksi usaha selama dua tahun memberikan nilai IRR diatas nilai NPV atau IRR $\geq$ $20 \%$ maka usaha tambak udang di Kecamatan Blanakan layak untuk dikembangkan.

\section{KESIMPULAN}

Implementasi program Demfarm di Kecamatan Blanakan Subang cukup efektif, hal tersebut dapat dilihat dari meningkatnya produktifitas tambak, pembukaan kembali lahan tambak serta pendapatan petambak. Peningkatan fungsi lahan tambak secara optimal mampu dilakukan melalui peran aktif pihak swasta seperti perusahaan pakan udang PT Centra Proteinaprima sebagai mitra penyuplai pakan sekaligus mendampingi Pokdakan secara teknis sampai dengan panen. Selain itu KUD Mina Karya Bukti Sejati memberikan jaminan stabilitas harga kepada para petambak sehingga usaha tambak udang di Kecamatan Blanakan Subang kondusif.

Pengembangan produktifitas tambak di Kecamatan Blanakan Kabupaten Subang sangat dipengaruhi oleh teknologi. Pendekatan dan pemanfaatan teknologi diyakini menjadi sumber pertumbuhan ekonomi berkesinambungan dalam jangka panjang karena kedua unsur tersebut saling memiliki keterkaitan (Aminullah 2004). Aktor yang memegang peran teknologi adalah pemerintah yang mempunyai kapasitas dalam mengkaji dan menerapkan teknologi. Kekuatan yang berperan atau berpengaruh keberhasilan usaha budidaya tambak udang yaitu hasil panen mudah dijual atau dengan kata lain pangsa pasar udang masih tinggi namun demikian kurangnya sarana dan prasarana menjadi kendala petambak udang hal tersebut disebabkan tingginya biaya/ 
modal yang dibutuhkan. Melalui program kemitraan, adanya tenaga teknisi atau pendamping baik dari sisi teknologi maupun manajemen sehingga ancaman yang besar seringkali terjadi pada usaha budidaya udang yaitu serangan virus dapat diminimalisir.

Usaha tambak udang di Kecamatan Blanakan Kabupaten Subang melalui program Demfarm sangat layak dikembangkan dengan nilai $\mathrm{B} / \mathrm{C}$ ratio $>1$ dan NPV yang dihasilkan $>0$. Siklus produksi empat bulan sehingga siklus produksi per tahun tiga kali dengan produktiftas lahan yang tinggi dan harga yang stabil, mampu menjaga stabilitas produksi udang.

\section{DAFTAR PUSTAKA}

Aminullah Erman. 2004. Berpikir Sistemik. Jakarta (ID). PPM.

Chusnul, D Z, at al. 2010. Kajian Sosial Ekonomi Usaha Budidaya Udang Vannamei Di Desa Dinoyo Kecamatan Deket Kabupaten Lamongan. [Jurnal]. Jurnal J-SEP Vol. 4. Univ. Jember.

Florina P. 2012. Adoption Of Good Management Practice In Small And Medium Scale Vannamei Shrimp Farms On The Northern Shore Of East Java. [Jurnal]. Jurnal Manajemen \& Agribisnis Vol. 9. IPB. Bogor.
Hargreaves A. 2013. Biofloc Production Systems for Aquaculture. [Journal] Southern Regional Aquaculture Center Publication No. 4503.

Kusumawardany D. 2010. Analisis Kelayakan Finansial Perluasan Tambak Budidaya Udang Vaname di Cantigi Indramayau. [Jurnal]. Jurnal Akuakultur Indonesia 9(1): 77-83.

Maulina I. 2012. Analisis Prospek Budidaya Tambak Udang di Kabupaten Garut. [Jurnal]. Jurnal Akuatika Vol. III. Unpad. Bandung.

Mudiastuti, et al. 2014. Strategi Kebijakan Industri Marine Politan Untuk Mendukung Konsep Maminasata. [Jurnal]. Jurnal Jemis Vol. 2. Unhas. Makassar.

Rahaju T. 2007 Implementasi Program Padat Karya: Studi Kasus tentang Pelaksanaan Program Padat Karya di Kelurahan Ciracas Kecamatan Ciracas Jakarta Timur. [Jurnal]. Jurnal Demokrasi Vol. VI No.1.

Sutanto HA. 2010. Pengelolaan Mangrove Sebagai Pelindung Kawasan Pesisir dengan Pendekatan C0-Management dan Analysis Hierarchy Process. [Jurnal]. Jurnal Prestasi Vol. 6 No.1 ISSN 1411-1497.

Umar Abidin. 2011. Pengembangan Agribisnis Terpadu di Sektor Perikanan. [Jurnal]. Jurnal Inovasi Vol. 8 ISSN 1693-9034. 